\title{
Underweight, overweight, and obesity in boys and girls at the age of 7-18 years from eastern Poland in the years 1986-2006
}

\section{Niedowaga, nadwaga i otyłość u chłopców i dziewcząt w wieku 7-18 lat ze wschodniej Polski w latach 1986-2006}

\author{
Agnieszka Wasiluk, Jerzy Szczuk \\ Department of Anthropology and Anthropomotorics, Faculty of Physical Education, Biala Podlaska, Poland \\ Head of the Department: Adam Wilczewski PhD
}

Key words: body mass index, girls, boys, secular trend.

Słowa kluczowe: wskaźnik masy ciała, dziewczęta, chłopcy, trend sekularny.

\begin{abstract}
Introduction: Increasing disproportions in the economic status of the Polish population are tangibly reflected in differences in the nutritional status of children and adolescents.

Aim of the research: The objective of this study was to determine changes in population size of boys and girls with proper body mass index (BMI) values and their peers with underweight, overweight, and obesity in a 20 -year time span.

Material and methods: The surveys were conducted in 1986 (52,853 boys and girls) and in 2006 (33,385 boys and girls). Height and weight of the body were measured and the BMI calculated for the boys and girls at the age of 7-18 years. Respondents with underweight (group I), with proper BMI values (group II), with overweight (group III), and with obesity (group IV) were selected from the biological material. The statistical significance of differences between mean values was verified with the Student's $t$-test and the $\chi^{2}$ test.

Results: Analyses demonstrated an increased incidence of body mass deficiency and excess in the surveyed boys and girls. Greater differences between the generations in the incidence of underweight, overweight, and obesity were observed in the urban citizens, compared to their rural peers. In addition, more significant differences in body mass deficiency and excess were noted in the youngest girls and boys from the schools in Eastern Poland.

Conclusions: It may be speculated that the differences in the economic status of the inhabitants of Eastern Poland influenced the lower number of girls and boys with appropriate BMI values, as well as increased percentages of girls and boys with body mass deficiency and excess.
\end{abstract}

\section{Streszczenie}

Wprowadzenie: Wraz ze zmieniającym się statusem społeczno-ekonomicznym polskiego społeczeństwa uwidaczniają się różnice w stanie odżywienia dzieci i młodzieży.

Cel pracy: Zbadanie zmian u chłopców i dziewczęt o właściwych proporcjach wagowo-wzrostowych i u ich rówieśników z niedowagą, nadwagą i otyłością, które dokonały się w ciągu 20 lat.

Materiał i metody: Badania przeprowadzono w 1986 (52 853 dziewczęta i chłopcy) oraz w 2006 r. (33 385 dziewcząt i chłopców). U chłopców i dziewcząt w wieku 7-18 lat zmierzono wysokość ciała, zważano masę ciała oraz obliczono wskaźnik masy ciała (body mass index - BMI). Z materiału badawczego wyselekcjonowano osoby z III stopniem niedowagi (grupa I), II stopniem niedowagi (grupa II), I stopniem niedowagi (grupa III), o prawidłowych proporcjach wagowo-wzrostowych (grupa IV), z nadwagą (grupa V) i otyłością (grupa VI). Istotność statystyczną różnic pomiędzy średnimi uzyskanymi w latach 1986 i 2006 weryfikowano testem $t$-Studenta oraz testem $\chi^{2}$.

Wyniki: W analizowanym 20-leciu odnotowano wzrost częstości występowania niedoboru i nadmiaru masy ciała u chłopców i dziewcząt. Większe zmiany międzypokoleniowe dotyczące częstości występowania niedowagi, nadwagi i otyłości zaobserwowano u mieszkańców miast $\mathrm{w}$ porównaniu z ich rówieśnikami ze wsi. Ponadto znaczne różnice w niedoborze i nadmiarze masy ciała zauważono u najmłodszych uczniów szkół województwa lubelskiego.

Wnioski: Można przypuszczać, że różnice w statusie ekonomicznym mieszkańców wschodniej Polski wpłynęły na zmniejszenie liczby dziewcząt i chłopców o prawidłowych proporcjach wagowo-wzrostowych oraz zwiększenie odsetka osób z niedoborem i nadmiarem masy ciała. 


\section{Introduction}

The civilization advance proceeding in many countries of Europe and the world contributes to lifestyle changes in entire societies. Achievements of human thought and their materialisation are accompanied by numerous adverse effects, the most severe of which includes reduced physical activity, which, as a consequence, increases the risk of overweight and obesity development $[1,2]$. An outcome of such a lifestyle is, among other things, an increased number of children with overweight and excessive body adiposity observed in the last two decades, especially in highly developed countries [3-6]. It is very often emphasised that obesity is the cause of many health disorders including: ischaemic heart disease, hypertension, type 2 diabetes, colon cancers, prostate cancer, etc. [7-9]. In contrast, body mass deficiency remains in a strict correlation with inflammatory lesions of bronchi and lungs, asthma, improper functioning of the digestive system, and emotional disorders [10, 11]

The last 20 years in Poland have been a period of abrupt socio-economic changes and transformations. In this period a new class of wealthy people has emerged, but on the other hand a considerable part of the population has become impoverished as a result of the liquidation of many workplaces and an increasing unemployment rate. The intensifying disproportions in the economic status of Polish society were accompanied by discernible differences in the nutritional status of children and adolescents. This problem is observed in regions of the country with higher economic indices and is beginning to be noticeable in the regions with a lower rate of development $[12,13]$.

It seems interesting, therefore, to determine the rate of changes in somatic traits of adolescents inhabiting poorly developed regions of the country.

\section{Aim of the research}

Hence, the objective of this study was to determine changes occurring within 20 years in the population of children and adolescents from eastern Poland, characterised by proper body mass to body height proportions and their peers with underweight, overweight, and obesity.

\section{Material and methods}

In 1985 and 1986 research was undertaken amongst children and adolescents inhabiting provinces from eastern Poland: Bialskopodlaskie, Chełmskie, Lubelskie, Zamojskie, Suwalskie, Białostockie, and Łomżyńskie. After the administrative transformation of the country, beginning in the year 1998, the aforementioned areas became part of the Podlaskie and Lubelskie Provinces. Based on the list of educational centres received from the Education Offices, 240 schools were selected for the study considering the settlement structure in these regions. The results of observations of 52,853 girls and boys at the age of 7-18 years, including 27,848 inhabitants of urban areas and 25,005 inhabitants of rural areas, were selected for this study from the collected material.

Observations of girls and boys were repeated in the same schools in 2005 and 2006, within statutory tasks of the Academy of Physical Education in Warsaw (D.S 45). This time the surveys covered results of 33,385 pupils at the age of $7-18$ years, including 17,964 and 15,421 inhabitants of urban and rural areas, respectively. The numbers of girls and boys at both stages of observations, considering their calendar age and place of residence, are presented in Table 1.

The survey was conducted following the principles of the Helsinki Declaration and was approved by

Table 1. Number of surveyed girls and boys from eastern Poland

\begin{tabular}{|lcccccc|}
\hline Age [years] & \multicolumn{3}{c}{1986} & & \multicolumn{2}{c|}{2006} \\
\cline { 2 - 7 } Boys & All & Town & Village & All & Town & Village \\
$7-9$ & & & & & & \\
$10-12$ & 5623 & 3282 & 2341 & 2666 & 1799 & 267 \\
$13-15$ & 7291 & 3893 & 3398 & 5221 & 2655 & 2566 \\
$16-18$ & 6361 & 3267 & 3094 & 5227 & 2452 & 2775 \\
$7-18$ & 5566 & 2918 & 2648 & 5668 & 2793 & 2875 \\
Girls & 24841 & 13,360 & 11,481 & 18,782 & 9699 & 9083 \\
$7-9$ & & & & & & 605 \\
$10-12$ & 5328 & 2938 & 2390 & 2222 & 1617 & 1648 \\
$13-15$ & 7458 & 3964 & 3494 & 3578 & 1930 & 1639 \\
$16-18$ & 7565 & 4023 & 3542 & 3731 & 2092 & 2446 \\
$7-18$ & 7661 & 3563 & 4098 & 5072 & 2626 & 6338 \\
\hline
\end{tabular}


the Senate Ethical Commission acting at the Academy of Physical Education in Warsaw.

A questionnaire was used to collect data on the date of birth and social conditions of the respondents.

Anthropometric measurements were taken according to standard anthropometric techniques (IBP). Body height and body mass values served to calculate the body mass index (BMI), defined as body mass (kg) of an individual divided by the square of their height (m). The BMI values obtained enabled children to be selected with: underweight (group I), normal BMI (group II), overweight (group III), and obesity (group IV). The children were classified to the above groups following recommendations of the Obesity Task Force, based on boundary values elaborated by Cole et al. $[14,15]$. The numbers of children in particular groups were then used to compute the percentages of girls and boys with underweight, overweight, and obesity in the entire material and in particular places of residence (rural, urban areas) or in groups considering stages of education (7-9 years of age - integrated education; 10-12 years - primary school; $13-15$ years - gymnasium; 16-18 years - post-gymnasium school). Arithmetic means and standard deviations were calculated for BMI values within the groups, considering the calendar age of the respondents.

\section{Statistical analysis}

The statistical significance of differences between mean values obtained in 1986 and 2006 was verified with Student's $t$-test for independent variables. The statistical significance of differences between the number of children classified to each group in rela- tion to the whole population surveyed in 1986 and 2006 was determined using the $\chi^{2}$ test.

\section{Results}

In the analysed twenty-year period, a significant decrease in the BMI value, by $1.07 \mathrm{~kg} / \mathrm{m}^{2}$ on average, was observed only in the group of the oldest girls. In the remaining groups, selected in terms of both gender and calendar age, a significant increase was noted in the relative body mass. An exception were girls from gymnasium, in whom the described differences were small $\left(0.07 \mathrm{~kg} / \mathrm{m}^{2}\right)$, which was confirmed by the results of Student's $t$-test (Table 2).

From 1986 to 2006, a significant decrease was noted in the percentage of boys with proper BMI values $(4.46 \%)$ and those with underweight (2.89\%), whereas an increase of $7.23 \%$ was determined in the percentage of pupils with overweight. Greater changes were observed in inhabitants of cities and smaller ones in those originating from rural areas (Table 3).

The above-described generation changes were not identical in all groups of calendar age. The highest statistically significant differences were observed in boys at the age of 7-9 years. This group was characterised with an increase of $3.71 \%$ in the percentage of pupils with underweight, and with an increase of $6.72 \%$ and $1.33 \%$ in the percentages of pupils with overweight and obesity, respectively, as well as a decrease of $-9.63 \%$ in the percentage of pupils with normal BMI value. In the case of boys from eastern Poland at the age of 10 to 18 years, a significant decrease was noted in the percentage of respondents with underweight and an increase in the percentage of those with overweight.

Table 2. Body mass index values of girls and boys from eastern Poland in the years 1986-2006

\begin{tabular}{|c|c|c|c|c|c|c|c|c|c|c|}
\hline \multicolumn{4}{|c|}{ Boys } & \multirow{3}{*}{$\begin{array}{c}\text { Student's } \\
t \text {-test }\end{array}$} & \multirow{3}{*}{$\begin{array}{c}\text { Age } \\
\text { [years] }\end{array}$} & \multicolumn{4}{|c|}{ Girls } & \multirow{3}{*}{$\begin{array}{c}\text { Student's } \\
t \text {-test }\end{array}$} \\
\hline \multicolumn{2}{|c|}{1986} & \multicolumn{2}{|c|}{2006} & & & \multicolumn{2}{|c|}{1986} & \multicolumn{2}{|c|}{2006} & \\
\hline $\bar{x}$ & SD & $\bar{x}$ & SD & & & $\bar{x}$ & SD & $\bar{x}$ & SD & \\
\hline 16.04 & 1.67 & 16.33 & 2.03 & $2.786^{\star}$ & 7 & 16.64 & 2.26 & 16.95 & 2.25 & $2.012^{*}$ \\
\hline 16.38 & 1.67 & 16.59 & 1.78 & $2.112^{\star}$ & 8 & 16.50 & 1.71 & 16.81 & 2.08 & $2.718^{\star}$ \\
\hline 17.15 & 1.65 & 17.39 & 2.32 & $2.224^{\star}$ & 9 & 16.89 & 1.64 & 17.19 & 2.34 & $2.539^{\star}$ \\
\hline 17.2 & 1.94 & 17.65 & 2.11 & $5.014^{*}$ & 10 & 17.0 & 1.96 & 17.23 & 2.43 & $2.249^{*}$ \\
\hline 17.71 & 1.96 & 17.93 & 2.07 & $2.557^{*}$ & 11 & 17.38 & 2.08 & 17.73 & 2.30 & $3.415^{\star}$ \\
\hline 17.63 & 2.11 & 18.5 & 2.17 & $9.572^{*}$ & 12 & 17.8 & 2.06 & 18.02 & 2.50 & $1.984^{\star}$ \\
\hline 18.59 & 1.78 & 19.64 & 2.09 & $11.620^{\star}$ & 13 & 18.88 & 2.09 & 19.03 & 2.33 & 1.318 \\
\hline 19.35 & 1.81 & 20.36 & 2.03 & $11.150^{*}$ & 14 & 19.62 & 1.86 & 19.51 & 2.01 & 1.046 \\
\hline 20.26 & 1.58 & 20.83 & 2.04 & $6.677^{\star}$ & 15 & 20.49 & 2.08 & 20.65 & 1.93 & 1.661 \\
\hline 21.52 & 1.77 & 21.8 & 2.16 & $2.513^{*}$ & 16 & 20.92 & 2.73 & 20.19 & 1.76 & $6.354^{\star}$ \\
\hline 21.37 & 1.69 & 22.3 & 1.9 & $9.188^{*}$ & 17 & 22.01 & 1.88 & 20.97 & 1.74 & $10.519^{*}$ \\
\hline 21.8 & 2.22 & 22.48 & 1.67 & $6.472^{*}$ & 18 & 21.83 & 1.81 & 20.39 & 1.70 & $14.609^{\star}$ \\
\hline
\end{tabular}

*Statistically significant differences at the level of $p \leq 0.05$. 
Table 3. Percentage of boys in groups with normal BMI, underweight, overweight, and obesity, considering the place of residence

\begin{tabular}{|c|c|c|c|c|c|c|c|c|c|}
\hline & & All & & & Town & & & Village & \\
\hline & 1986 & 2006 & Test $\chi^{2}$ & 1986 & 2006 & $\chi^{2}$ & 1986 & 2006 & $\chi^{2}$ \\
\hline $7-18$ & & & & & & & & & \\
\hline Underweight & 10.28 & 7.40 & $92.303^{*}$ & 10.75 & 7.83 & $47.093^{\star}$ & 9.74 & 6.94 & $42.691^{*}$ \\
\hline Normal & 81.04 & 76.58 & $15.104^{*}$ & 79.75 & 74.69 & $10.480^{\star}$ & 82.55 & 78.60 & $17.890^{\star}$ \\
\hline Overweight & 7.35 & 14.57 & $477.004^{\star}$ & 7.93 & 15.71 & $268.496^{\star}$ & 6.67 & 13.35 & $376.325^{\star}$ \\
\hline Obesity & 1.33 & 1.45 & 1.189 & 1.58 & 1.77 & 1.246 & 1.04 & 1.11 & $9.745^{\star}$ \\
\hline 7-9 & & & & & & & & & \\
\hline Underweight & 9.46 & 13.17 & $20.248^{*}$ & 9.11 & 12.73 & $12.860^{\star}$ & 9.95 & 14.07 & $8.264^{*}$ \\
\hline Normal & 80.90 & 71.27 & $12.404^{\star}$ & 80.20 & 70.93 & $7.466^{\star}$ & 81.89 & 71.97 & $4.512^{\star}$ \\
\hline Overweight & 7.56 & 12.15 & $36.755^{\star}$ & 8.32 & 12.56 & $18.707^{\star}$ & 6.49 & 11.30 & $16.054^{\star}$ \\
\hline Obesity & 2.08 & 3.41 & $11.855^{\star}$ & 2.38 & 3.78 & $7.451^{\star}$ & 1.67 & 2.65 & 2.926 \\
\hline 10-12 & & & & & & & & & \\
\hline Underweight & 11.22 & 9.08 & $12.417^{\star}$ & 12.02 & 9.98 & $5.356^{*}$ & 10.30 & 8.14 & $6.719^{\star}$ \\
\hline Normal & 79.59 & 74.83 & $5.025^{\star}$ & 78.14 & 72.81 & 3.382 & 81.25 & 76.93 & 1.927 \\
\hline Overweight & 7.80 & 14.52 & $114.594^{*}$ & 8.27 & 15.37 & $62.519^{*}$ & 7.27 & 13.64 & $53.139^{*}$ \\
\hline Obesity & 1.39 & 1.57 & 0.700 & 1.57 & 1.85 & 0.711 & 1.18 & 1.29 & 0.139 \\
\hline 13-15 & & & & & & & & & \\
\hline Underweight & 12.47 & 7.00 & $80.593^{*}$ & 12.55 & 6.61 & $47.234^{\star}$ & 12.38 & 7.35 & $34.358^{*}$ \\
\hline Normal & 79.56 & 75.24 & $3.894^{*}$ & 78.54 & 73.37 & 2.800 & 80.64 & 76.90 & 1.452 \\
\hline Overweight & 6.90 & 16.64 & $217.405^{\star}$ & 7.71 & 18.84 & $122.245^{\star}$ & 6.04 & 14.70 & $99.947^{\star}$ \\
\hline Obesity & 1.07 & 1.11 & 0.043 & 1.19 & 1.18 & 0.001 & 0.94 & 1.05 & 0.170 \\
\hline 16-18 & & & & & & & & & \\
\hline Underweight & 6.61 & 3.49 & $75.982^{\star}$ & 8.88 & 3.69 & $59.209^{\star}$ & 5.74 & 3.30 & $17.596^{*}$ \\
\hline Normal & 73.37 & 81.92 & 1.510 & 82.73 & 80.06 & 0.689 & 87.05 & 83.72 & 0.963 \\
\hline Overweight & 18.84 & 13.85 & $114.955^{\star}$ & 7.27 & 15.32 & $75.783^{\star}$ & 6.80 & 12.42 & $41.825^{*}$ \\
\hline Obesity & 1.18 & 0.74 & 0.089 & 1.13 & 0.93 & 0.549 & 0.42 & 0.56 & 0.563 \\
\hline
\end{tabular}

*Statistically significant differences at the level of $p \leq 0.05$.

Less significant generation changes were observed in girls (Table 4). A statistically significant increase of $4.08 \%$ was reported in the percentage of girls with underweight; whereas a significant decrease was noted in the percentage of those with proper BMI values $(-3.59 \%)$. No significant differences were determined in the remaining groups selected based on BMI values. Similar generation changes were noted in the places of residence groups, with greater differences noted in girls from rural areas. This group was characterised by a $5.59 \%$ higher percentage of pupils with underweight, whereas a decrease of $4.16 \%$ and $1.19 \%$ was determined in the percentage of pupils with proper BMI and overweight, respectively.

Assessing changes with regard to calendar age, the population of girls was characterised by a signifi- cant increase in the percentage of respondents with body mass deficiency. In the analysed groups, apart from the girls in the age category of 10-12 years, the reported differences were significant and the greatest differences were determined in the oldest girls. In addition, from 1986 to 2006, in the age category of 7-9 years, the percentage of girls with normal BMI values was observed to decrease by $12.65 \%$, whereas that of girls with overweight increased by $8.03 \%$. In the case of girls from primary schools, the percentage of pupils with overweight decreased by $3.15 \%$. In the group of girls attending gymnasiums, the percentage of girls with underweight increased by $2.46 \%$ and that of girls with normal BMI decreased by $2.48 \%$. In turn, in the age category of 16-18 years, an increase was observed in the percentage of girls with under- 
Table 4. Percentage of girls in groups with normal BMI, underweight, overweight, and obesity, considering the place of residence

\begin{tabular}{|c|c|c|c|c|c|c|c|c|c|}
\hline & \multicolumn{3}{|c|}{ All } & \multicolumn{3}{|c|}{ Town } & \multicolumn{3}{|c|}{ Village } \\
\hline & 1986 & 2006 & $\chi^{2}$ & 1986 & 2006 & $\chi^{2}$ & 1986 & 2006 & $\chi^{2}$ \\
\hline \multicolumn{10}{|l|}{$7-18$} \\
\hline Underweight & 13.12 & 17.20 & $93.169^{*}$ & 13.94 & 16.71 & $23.161^{\star}$ & 12.24 & 17.83 & $80.375^{\star}$ \\
\hline Normal & 77.39 & 73.80 & $9.280^{*}$ & 76.64 & 73.62 & 3.636 & 78.19 & 74.03 & $5.540^{\star}$ \\
\hline Overweight & 8.41 & 8.09 & 1.050 & 8.21 & 8.60 & 0.907 & 8.62 & 7.43 & $6.992^{*}$ \\
\hline Obesity & 1.09 & 0.91 & 2.876 & 1.21 & 1.06 & 1.023 & 0.95 & 0.71 & 2.850 \\
\hline \multicolumn{10}{|l|}{ 7-9 } \\
\hline Underweight & 13.74 & 16.74 & $8.192^{*}$ & 14.23 & 17.38 & $5.731^{\star}$ & 13.14 & 15.04 & 1.106 \\
\hline Normal & 75.88 & 63.23 & $20.957^{\star}$ & 74.47 & 61.16 & $16.062^{\star}$ & 77.62 & 68.76 & 2.939 \\
\hline Overweight & 8.71 & 17.01 & $80.078^{\star}$ & 9.22 & 18.06 & $55.595^{\star}$ & 8.08 & 14.21 & $15.894^{*}$ \\
\hline Obesity & 1.67 & 3.02 & $12.520^{*}$ & 2.08 & 3.40 & $6.740^{\star}$ & 1.17 & 1.98 & 2.123 \\
\hline \multicolumn{10}{|l|}{ 10-12 } \\
\hline Underweight & 17.16 & 16.99 & 0.035 & 17.16 & 16.63 & 0.003 & 16.70 & 16.63 & 0.040 \\
\hline Normal & 73.84 & 70.93 & 1.632 & 73.84 & 71.45 & 0.495 & 73.64 & 71.45 & 1.256 \\
\hline Overweight & 7.92 & 11.07 & $23.595^{\star}$ & 7.92 & 11.09 & $8.771^{*}$ & 8.43 & 11.09 & $15.690^{*}$ \\
\hline Obesity & 1.07 & 1.01 & 0.102 & 1.07 & 0.83 & 2.030 & 1.24 & 0.83 & 1.150 \\
\hline \multicolumn{10}{|l|}{ 13-15 } \\
\hline Underweight & 13.03 & 15.49 & $9.381^{*}$ & 13.72 & 15.49 & 0.776 & 12.25 & 16.53 & $12.793^{*}$ \\
\hline Normal & 77.41 & 77.75 & 0.022 & 77.21 & 77.75 & 0.176 & 77.64 & 76.75 & 0.064 \\
\hline Overweight & 8.59 & 6.11 & $19.203^{\star}$ & 8.23 & 6.11 & $7.488^{*}$ & 9.01 & 6.04 & $11.964^{*}$ \\
\hline Obesity & 0.96 & 0.64 & 3.141 & 0.85 & 0.64 & 0.921 & 1.10 & 0.67 & 2.273 \\
\hline \multicolumn{10}{|l|}{$16-18$} \\
\hline Underweight & 8.84 & 18.79 & $202.960^{\star}$ & 10.86 & 17.97 & $47.585^{\star}$ & 7.08 & 19.66 & $175.626^{*}$ \\
\hline Normal & 81.87 & 77.54 & $3.977^{\star}$ & 81.14 & 78.98 & 0.489 & 82.50 & 76.00 & $4.538^{*}$ \\
\hline Overweight & 8.48 & 3.55 & $116.797^{\star}$ & 7.10 & 2.89 & $51.525^{\star}$ & 9.69 & 4.25 & $60.340^{\star}$ \\
\hline Obesity & 0.81 & 0.12 & $33.312^{*}$ & 0.90 & 0.15 & $16.998^{\star}$ & 0.73 & 0.08 & $16.992^{\star}$ \\
\hline
\end{tabular}

*Statistically significant differences at the level of $p \leq 0.05$.

weight (by 9.95\%), whereas percentages of girls with proper BMI, overweight, and obesity were observed to decrease (by 4.33\%, 4.93\%, and 0.69\%, respectively). The other differences were negligible and statistically insignificant.

\section{Discussion}

The economic crisis of the 1970s and 1980s as well as socio-economic transformations proceeding in Poland since 1989 and their differentiated pace in particular regions affected the extent of secular trends in somatic traits. Based on surveys conducted in that period with adolescents from the whole country, the values of somatic traits were observed to increase, with the increase varying depending on both the period and area of observations. The environment the girls and boys were growing up in was confirmed to still modify their developmental process to various extents in different regions of Poland [16-18]. Higher body height values and a significant increase in body mass were also determined in girls and boys from eastern Poland [19]. Hence, it is obvious that the research conducted in eastern Poland in 2006 revealed higher BMI values compared to the mean values achieved in 1986 .

Contemporarily, a declining tendency is being observed globally in the number of children and adolescents with body mass deficiency and a growing tendency in the number of individuals with excessive body mass. Such a trend may be noticed in developing countries as well as in highly developed ones $[3,5$, 
6]. Such changes are more noticeable amongst inhabitants of urban rather than rural areas. Such conclusions were formulated by Wang et al. [20], based on research with schoolgirls and schoolboys from Brazil, China, Russia, and the USA. They were seeking reasons of the changes in differences in nutritional habits and reduced physical activity. The observed global trend of the increasing number of persons with overweight and obesity is also slowly spreading in Poland. Currently, Polish adolescents, including those from eastern Poland, are characterised by the lowest overweight and obesity rates compared to results noted for their peers in the European Union or the USA [20-22]. However, in the years 1995-2005 the frequency of overweight and obesity occurrence in Polish school adolescents increased by $2.4 \%$ and $1.5 \%$ in boys and by $2.0 \%$ and $2.0 \%$ in girls, respectively [21]. In eastern Poland from 1986 to 2006 the tendency for a decreasing number of children and adolescents with body mass deficiency and for an increasing number of individuals with body mass excess was observed only in the case of boys, with greater differences noted in boys from urban areas than in boys from rural areas. The causes of the differences in BMI values over the 20 -year period ought to be searched for in changes taking place in the socio-economic conditions of the country, as described in the Introduction section. The picture of the described secular trends is undoubtedly influenced by the place of residence. The problem of unemployment affected to a greater extent inhabitants of cities, because in rural areas it was easier to provide for the family in small farms. In addition, rural children more frequently participated in work on the farm, which could be reflected in their higher physical activity. Therefore, tangible generation changes were not observed in the case of girls who are less eco-sensitive than boys.

What is alarming is the increasing percentage of schoolgirls with a significant body mass deficiency observed especially in girls living in cities, which has not been observed in many countries. It should also be emphasised that increasing silhouette slenderness (reflected in decreasing BMI values) and a decreasing percentages of girls with overweight and obesity were observed in the oldest age category of girls. The reasons behind these changes should be looked for in the consciousness of the surveyed schoolgirls, namely in their lifestyle, nutrition, etc. Also of great significance is contemporary fashion and the desire for a slim figure. In this case, it is worth noting that in 1986 the girls from the eastern provinces of Poland were characterised by significantly higher body adiposity compared to ordinary Polish girls and girls from large cities [19]; therefore, the observed tendency of changes may be acknowledged as positive. The greatest number of statistically significant differences was noted in the youngest children from eastern Poland. This may suggest that a greater percentage of the young generation will be characterised by improper mass-to-height proportions.

Confirmation of these observations requires more extensive social research.

\section{Conclusions}

The analysis of the study material enables the formulation of the following conclusions and observations: the effects of civic transformations observed worldwide are beginning to enter areas of eastern Poland, which is reflected in increasing BMI values and increasing percentages of boys and young girls with excessive body mass. What is alarming is the increased percentage of schoolgirls and schoolboys with significant body mass deficiency, which may indicate their malnutrition and may trigger inflammatory states of bronchi and lungs, asthma, improper functioning of the digestive system, and emotional disorders. The greatest generation changes in the mass-to-height proportions were noted in the youngest children from eastern Poland. This may suggest that a greater percentage of the young generation will be characterised by improper mass-to-height proportions. Therefore, classes of physical education should be held by teachers of physical education and not by teachers of integrated education.

\section{Conflict of interest}

The authors declare no conflict of interest.

\section{References}

1. Healy GN, Wijndaele K, Dunstan DW, et al. Objectively measured sedentary time, physical activity, and metabolic risk: the Australian Diabetes, Obesity and Lifestyle Study (AusDiab). Diabetes Care 2008; 31: 369-71.

2. Thibault H, Contrand B, Saubusse E, et al. Risk factors for overweight and obesity in French adolescents: physical activity, sedentary behavior and parental characteristics. Nutrition 2010; 26: 192-200.

3. Kosti RI, Panagiotakos DB. The epidemic of obesity in children and adolescents in the world. Cent Eur J Public Health 2006; 14: 151-9.

4. Ahrens W, Pigeot I, Pohlabeln H, et al. Prevalence of overweight and obesity in European children below the age of 10. Int J Obes 2014; 38 Suppl 2: S99-107.

5. Ahluwalia N, Dalmasso P, Rasmussen M, et al. Trends in overweight prevalence among 11-, 13- and 15-year-olds in 25 countries in Europe, Canada and USA from 2002 to 2010. Eur J Public Health 2015; 25 Suppl 2: 28-32.

6. Valera B, Sohani Z, Rana A, et al. The ethnoepidemiology of obesity. Can J Cardiol 2015; 31: 131-41.

7. Bonn SE, Wiklund F, Sjölander A, et al. Body mass index and weight change in men with prostate cancer: progression and mortality. Cancer Causes Control 2014; 25: 933-43.

8. Pires A, Martins P, Pereira AM, et al. Insulin resistance, dyslipidemia and cardiovascular changes in a group of obese children. Arq Bras Cardiol 2015; 104: 266-73. 
9. Tandon K, Imam M, Ismail BE, et al. Body mass index and colon cancer screening: the road ahead. World J Gastroenterol 2015; 21: 1371-6.

10. Halldin CN, Doney BC, Hnizdo E. Changes in prevalence of chronic obstructive pulmonary disease and asthma in the US population and associated risk factors. Chron Respir Dis 2015; 12: 47-60.

11. Mond J, Rodgers B, Hay P, et al. Mental health impairment in underweight women: do body dissatisfaction and eating-disordered behavior play a role? BMC Public Heath 2011; 11: 547.

12. Chrzanowska M, Suder A. The extent of overweight index in children and adolescents from Cracow, Poland (1971-2000). HOMO 2010; 61: 453-8.

13. Grajda A, Kułaga Z, Gurzkowska B, et al. Regional differences in the prevalence of overweight, obesity and underweight among Polish children and adolescents. Med Wieku Rozwoj 2011; 15: 258-65.

14. Cole TJ, Bellizzi MC, Flegal KM, et al. Establishing a standard definition for child overweight and obesity worldwide: international survey. BMJ 2000; 320: 1240-3.

15. Cole TJ, Flegal KM, Nicholls D, et al. Body mass index cut offs to define thinness in children and adolescents: international survey. BMJ 2007; 335: 194-7.

16. Przewęda R, Dobosz J. Growth and physical fitness of Polish youths. University of Physical Education Editions, Warsaw 2005

17. Łaska-Mierzejewska T, Olszewska E. Anthropological assessment of changes in living conditions of the rural population in Poland in the period 1967-2001. Ann Hum Biol 2007; 3: 362-76.

18. Bielicki T, Szklarska A, Kozieł S, et al. Changing patterns of social variation in stature in Poland: effects of transition from a command economy to the free-market system? J Biosoc Sci 2005; 37: 427-34.

19. Saczuk J, Wasiluk A, Changes in the somatic and fitness variables in girls over two decades. Biomed Human Kinet 2010; 2: 102-5.

20. Wang Y, Monteiro C, Popkin BM. Trends of obesity and underweight in older children and adolescents in the United States, Brazil, China, and Russia. Am J Clin Nutr 2002; 75: 971-7.

21. Oblacińska A, Jodkowska M. Otyłość u polskich nastolatków. Epidemiologia, styl życia, samopoczucie. Instytut Matki i Dziecka, Warsaw 2007.

22. Tokmakidis A, Christodulos D, Savvas P. Fitness levels of Greek primary schoolchildren in relationship to overweight and obesity. Eur J Pediatr 2006; 165: 867-74.

\section{Address for correspondence:}

\section{Agnieszka Wasiluk}

Department of Anthropology and Anthropomotorics

Faculty of Physical Education

ul. Akademicka 2, 21-500 Biala Podlaska, Poland

Phone: +48 833428740

E-mail: agnieszka.wasiluk@awf-bp.edu.pl 